ORIGINAL ARTICLE

DOI: 10.17709/2409-2231-2017-4-1-3

\title{
BIOLOGICAL AND SYNTHETIC MESH USE IN RECONSTRUCTIVE SURGERY IN PATIENTS WITH BREAST CANCER
}

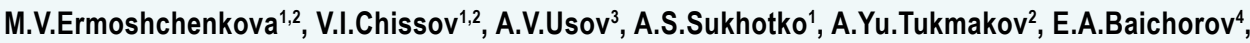 \\ A.D.Zikiryahodjaev
}

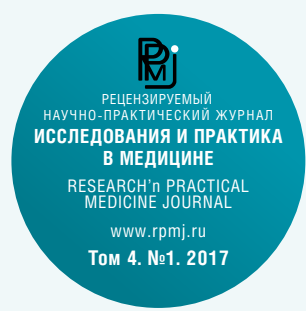

${ }^{1}$ P. Hertsen Moscow Oncology Research Institute - Branch of the National Medical Research Radiological Centre of the Ministry of Health of the Russian Federation, 3, 2nd Botkinskiy proezd, Moscow, 125284, Russia;

${ }^{2}$ I.M. Sechenov First Moscow State Medical University, the Ministry of Health of the Russian Federation,

8/2 ul. Trubetskaya, Moscow, 119992, Russia;

${ }^{3}$ Oncology Institute of European Medical Center in Moscow, 35 ul. Shchepkina, Moscow 129090, Russia;

${ }^{4}$ The Stavropol State Medical University, 310 ul. Mira, Stavropol' 355017, Russia

\section{ABSTRACT}

Introduction. In recent years, considerable success has been achieved in complex and combined treatment of breast cancer (BC). Reconstructive plastic surgery plays an important role in the rehabilitation of patients with breast cancer and it is currently considered as the causal treatment of mental disorders caused by loss of femininity and integrity of one's own body. One-step breast reconstruction for cancer treatment makes it possible to use supplementary materials - synthetic and biological implants that can replace muscle autografts and thereby reduce trauma, blood loss, operation time, and thereby help to avoid the defect of donor areas. The authors describe the state of the art at present and demonstrate the results of their own research.

Materials and methods. The object of study was 38 of breast cancer cases and 1 case of multiple gelioma caused by silicone implant rupture. 44 operations have been completed: 21 - radical subcutaneous mastectomy, 1 subcutaneous mastectomy, 17 - skin-sparing radical mastectomy with one-step reconstruction with mesh implant (12 - titanium, 16 - polyester), 11 - acellular dermal matrix Permacol, 5-prophylactic contralateral subcutaneous mastectomy with one-step reconstruction with silicone implant and a mesh implant due to a mutation of the $B R C A 1$ gene. The technique of operations and the results of studies have been described in detail.

Results. In the late post-operational period, the implants were removed in 5 cases: in 2 patients due to the development of inflammation of ADM, 3 - in connection with the development of bedsores and diastasis of the skin in the wound area when synthetic implants were used. From the total number of patients in the group $(n=39)$ excellent cosmetic results were reported in 21 cases (54\%), good - in $13(33 \%)$ and unsatisfactory - in $5(13 \%)$ cases due to the removal of the implants.

Conclusions. Biological and synthetic materials are significantly important options for breast reconstruction. They are adequate substitutes for autologous muscle flaps if the patients for the operation are properly select.

\section{KEYWORDS:}

breast cancer, implant-based subcutaneous mastectomy, implant-based skin-sparing mastectomy, acellular dermal matrix (ADM), mesh implant

\section{For citation:}

Ermoshchenkova M. V., Chissov V.I., Usov A. V., Sukhotko A. S., Tukmakov A.Yu., Baichorov E. A., Zikiryahodjaev A. D. Biological and Synthetic Mesh Use in Reconstructive Surgery in Patients with Breast Cancer. Research'n Practical Medicine Journal. 2017; 4 (1):23-32. DOI: 10.17709/2409-2231-2017-4-1-3

\section{For correspondence:}

Maria V. Ermoshchenkova, PhD, researcher, surgeon, oncologist, plastic surgeon of the Department of Oncology and Reconstructive Plastic Breast and Skin Surgery of P. Hertsen Moscow Oncology Research Institute - Branch of the National Medical Research Radiological Centre of the Ministry of Health of the Russian Federation, associate professor of the Department of Oncology and Radiotherapy of the Institute of Professional Education, I. M. Sechenov First Moscow State Medical University Address: 3, 2 $2^{\text {nd }}$ Botkinskiy proezd, Moscow, 125284, Russia; E-mail: maryerm@mail.ru 
ОРИГИНАЛЬНАЯ СТАТЬЯ

DOI: $10.17709 / 2409-2231-2017-4-1-3$

\title{
ПРИМЕНЕНИЕ БИОЛОГИЧЕСКИХ И СИНТЕТИЧЕСКИХ МАТЕРИАЛОВ ПРИ РЕКОНСТРУКТИВНО-ПЛАСТИЧЕСКИХ ОПЕРАЦИЯХ У БОЛЬНЫХ РАКОМ МОЛОЧНОЙ ЖЕЛЕЗЫ
}

\author{
М.В.Ермощенкова ${ }^{1,2}$, В.И.Чиссов ${ }^{1,2}$, А.В.Усов ${ }^{3}$, А.С.Сухотько ${ }^{1}$, А.Ю.Тукмаков ${ }^{2}$, \\ Э.А.Байчоров ${ }^{4}$, А.Д.Зикиряходжаев ${ }^{1,2}$ \\ ${ }^{1}$ Московский научно-исследовательский онкологический институт им. П.А. Герцена - филиал ФГБУ \\ «Национальный медицинский исследовательский радиологический центр» Минздрава России, \\ 125284, Россия, Москва, 2-й Боткинский проезд, 3; \\ 2 ГБОУ ВПО «Первый Московский государственный медицинский университет им. И.М. Сеченова» Минздрава России, \\ 119992, Россия, Москва, ул. Трубецкая, 8, стр. 2; \\ ${ }^{3}$ Институт онкологии Европейского медицинского центра, 129090, Россия, Москва, ул. Щепкина, 35; \\ ${ }_{4}^{4}$ ГБОУ ВПО «Ставропольский медицинский университет» Минздрава России, 355017, Россия, Ставрополь, ул. Мира, 310
}

\section{PE3ЮME}

\begin{abstract}
Введение. За последние годы достигнуты значительные успехи в комплексном и комбинированном лечении рака молочной железы (РМЖ). Реконструктивно-пластические операции занимают главное место в реабилитации больных РМЖ и в настоящее время рассматриваются как этиотропное лечение психических расстройств, связанных с утратой женственности и целостности собственного органа. При одномоментной реконструкции молочной железы по поводу рака актуальным становится применение дополнительных материалов - синтетических и биологических имплантатов, способных заменить мышечные аутотрансплантаты и тем самым сократить травматичность, кровопотерю, время операции, избежать дефектов донорских зон. В статье представлен обзор литературы и результаты собственных исследований.
\end{abstract}

Материалы и методы. Объектом исследования явились 38 случаев рака молочной железы и 1 случай множественных гелиом в результате разрыва силиконовых имплантатов. Выполнено 44 операции: 21 - радикальная подкожная мастэктомия, в 1 - подкожная мастэктомия, 17 - радикальная кожесохранная мастэктомия. с одномоментной реконструкцией сетчатым имплантатом (12 - титанированные, 16 - полиэстеровые), 11 ацеллюлярным дермальным матриксом Permacol, 5 - профилактические подкожные мастэктомии с контралатеральной стороны с одномоментной реконструкцией силиконовым эндопротезом и сетчатым имплантатом в связи в мутацией гена BRCA1. Описаны методики операций, результаты гистологических исследований в общей группе.

Результаты. В позднем послеоперационном периоде имплантаты были удалены в 5 случаях: у 2 пациенток в связи с развитием воспалительных явлений при применении АДМ, 3 - в связи с развитием пролежня и диастаза кожных покровов в области раны при применении синтетических имплантатов. В общей группе $(\mathrm{n}=39)$ отличные косметические результаты составили 21 (54\%), хорошие - 13 (33\%), неудовлетворительные -5 (13\%) (в связи с удалением имплантатов).

Выводы. Биологические и синтетические материалы являются существенным дополнением к вариантам реконструкции молочной железы, во многих случаях - адекватной заменой аутологичных мышечных лоскутов при правильном отборе больных.

\section{КЛЮЧЕВЫЕ СЛОВА:}

рак молочной железы, кожесохранная радикальная мастэктомия с одномоментной реконструкцией имплантатом, подкожная радикальная мастэктомия с одномоментной реконструкцией имплантатом, ацеллюлярный дермальный матрикс (АДМ), сетчатый имплантат

\section{Оформление ссылки для цитирования статьи:}

Ермощенкова М. В., Чиссов В.И., Усов А. В., Сухотько А. С., Тукмаков А. Ю., Байчоров Э. А., Зикиряходжаев А. Д. Применение биологических и синтетических материалов при реконструктивно-пластических операциях у больных раком молочной железы. Исследования и практика в медицине. 2017; 4 (1): 23-32. DOI: 10.17709/2409-2231-2017-4-1-3

\footnotetext{
Для корреспонденции

Ермощенкова Мария Владимировна, к. м.н., научный сотрудник отделения онкологии и реконструктивно-пластической хирургии молочной железы и кожи Мниои им. П. А. Герцена - филиал ФГБУ «НМИРЦ» Минздрава России,

Адрес: 125284, Россия, Москва, 2-й Боткинский проезд, 3; E-mail: maryerm@mail.ru

Инсормация о финансировании

Финансирование исследования отсутствует. Лечение больных осуществлено за счет государственных средств для оказания высокотехнологичной медицинской помощи. 
Breast cancer is one of the most common types of cancer of female population, accounting for $20,7 \%$ of total malignant neoplasms in Russia [1].

Considerable success in complex treatment of breast cancer has been achieved in recent years. The quality of life in patients decreases dramatically as a result of the radical treatment. Reconstructive plastic surgery plays a significant role in the rehabilitation of patients with breast cancer and is currently considered as causative treatment of mental disorders associated with the loss of femininity and integrity of one's own body [2-5].

About $50 \%$ of patients after mastectomy desire to restore their breast [6]. Recently there has been an increase in the number of patients wishing immediate reconstruction as it might help to avoid psychological collapse and depression connected with the loss of femininity $[7,8]$.

A compulsory condition for a good result is to achieve symmetry on the contralateral breast, which means that surgery on it is necessary [9-11].

Methods of breast reconstruction can be classified into three groups: reconstruction with synthetic material (expanders and implants), those with patients' own tissues and a combination of them [11-14]. The first group includes two-step operations with primary expander dermotension and subsequent endoprosthesis replacement [15-17]. The second group of operations includes autografts such as thoracodorsal flap (TDF), TRAM-flap, DIEP-flap, gluteal flap, lateral flap of thigh and Rubens flap. The third group is considered to be a combination of these methods when, in addition to patients' own tissues, an implant is used as well as techniques with the formation of a submuscular pocket when using mesh or biological implants [18-20].

If immediate reconstruction is made, important anatomical structures are maintained: such as submammary fold, the amount of skin remains the maximum required for the reconstructive phase, which improves the overall aesthetic result of the operation [21].

Radical subcutaneous and skin-sparing mastectomy is an alternative to radical mastectomy, which allows for primary rehabilitation in the correct selection of patients. In 1917, W. Bartlett performed the first subcutaneous mastectomy with simultaneous replacement of the removed breast tissue by adipose tissue [22]. B.S. Freeman., V.R. Pennisi, J.E. Woods and others developed this surgery method for breast reconstruction by using silicone implants in combination with local tissues. Different muscle autografts are used in the process of reconstruction with silicone prosthesis (TDF, TRAM). However, this method is often associated with increased risk of infection: it requires separation of the vascular pedicle and can cause a number of complications such as long-lasting lymphorrhea in the donor area while separating the latissimus dorsi muscle flap, the scar in the donor area (often with the deformation of the contour of the back or the anterior abdominal wall), followed by reduction in the volume of the TDF due to denervation and reduction in TDF volume with preserved motor nerve, risk of marginal necrosis, liposclerosis, adiponecrosis when using TRAM-flap, risk of thrombosis of microvascular anastomoses in case of microsurgical TRAM technic.

Therefore, the use of artificial materials is relevant because they can replace muscle autografts and by that can reduce trauma, blood loss, operation time and prevent the defect of donor areas.
In 1950, Cumberland and Scales formulated the criteria for the ideal implant for the first time. Later, their ideas were developed and modified according to the requirements of modern surgery. Thus, the ideal implant should possess the following characteristics: chemical inertness, resistance to infection (monofilament materials), histological inertness, minimal irritant effect on the surrounding tissue, the constancy of physical-chemical and mechanical properties, elasticity and flexibility to maintain the integrity in the modeling and mechanical strength. It should also allow collagen to grow and unite with patients' own tissues; it should have sufficient pore size for ingrowth of connective tissue ( $>75$ micron), should stimulate fibroblast growth, should be suitable for mass production and sterilization; its price should be affordable. The implant material must not be softened by the liquid extracted from the wound, it must not be a cause of inflammation or rejection, it must not shrink in the healing process, it must not cause allergy or sensitivity, be carcinogenic and initiate local complications [23-25].

The first propylene mesh - Marlex-50 - was introduced by Frencis C. Usher in 1958-59. The author provided data of high-density polyethylene stitching used in plastic defects of thoracic and abdominal walls. He described this new material as durable and elastic, impermeable to water, resistant to various chemical reagents and as a well-germinating connective tissue. Polypropylene mesh implants appeared in 1962, received the common name of "mesh" and started to be widely used because of high elasticity and optimal pore size. Thanks to the work of Lichtenstein (1989), polypropylene mesh, implants have become the standard material currently used in surgery [25, 27].

Mesh implant, after installation, causes an inflammatory reaction in local tissue as a response to a foreign substance.

There are a large number of different types of mesh implants on the market [26].

In 2002, C. Amanti (Italy) was the first to report results of using polypropylene mesh implants for one-stage breast reconstruction after mastectomy during which Madden's technique was applied. This surgical technique was developed in 1994 and consisted in the formation of submuscular pocket which was formed with a mesh implant placed along the pectoralis major muscle edge. Silicone implants were used, and, if necessary, pre-stretching of the skin by expander was performed. This technique was tested on 6 patients. Postoperative complications were not found and good cosmetic results were obtained, which promised excellent prospects of this method.

In 2005, results were presented from 67 one-step and 6 delayed reconstructions with non-absorbable mesh implants to support the abdominal skin flap with extensive skin excision. 14 cases $(19,2 \%)$ required a second surgical intervention under general anesthesia due to the movement of the prosthesis, displacement of the nipple-areola complex and elimination of capsular contracture. In 3 cases $(4.1 \%)$, the prosthesis was removed because of infection or displacement. The patients' assessment of the result was done by using a 10-point scale: the symmetry of the breast, the cosmetic effect, the general satisfaction with surgery. The result was $7,45-7,56$ points. The authors recommended this operation for further use [14].

M. Rietjens (2007) used non-absorbable mesh implants for tightening and maintaining the abdominal skin flap in extensive excision of the skin of the breast - «supporting technique». During 
the operation, a broad flap of tissue from anterior abdominal wall on anterior surface of rectus abdominis was mobilized. In the same way, skin and subcutaneous adipose tissue at the bottom edge of mastectomy wounds were mobilized. The mobilized flap of an anterior abdominal wall was pulled up and stitched to a triangular non-absorbable mesh implant fixed at the level of forming inframammary fold. The implant was pulled up and placed behind the pectoralis major muscle, its upper edge fixed to the rib cartilage by two prolen's seams. The prosthesis was installed at the front of the grid and behind the pectoralis major muscle. Basing their opinion on the results of the studies, the authors pointed out that the advantage of this operation is the ability to perform immediate reconstruction with extensive excision of the skin without prior skin stretching by expander and using a musculocutaneous flap.

H.D. Loustau put across an idea to perform breast reconstruction after radical subcutaneous mastectomy with a silicone implant with the formation of intra-muscular pockets using a mesh implant. The subpectoral pocket included the pectoralis major muscle (medial border), the serratus anterior (lateral margin) and the rectus abdominis muscles (lower edge). The author called this technique the «guaranteed subpectorally pocket» $[28,29]$. In his study, the author analyzed 34 breast reconstructions after subcutaneous mastectomy due to cancer treatment with the implantation of absorbable polyglycol mesh implant and silicone implant (the size is from 270 to $375 \mathrm{~cm} 3$ ). The average period of monitoring was 2,8 years. The formation of capsular contractures, infections, failures of the walls of the pocket for the implant were not observed.

R. Wettstein used the method of forming the pocket worked out by H.D. Loustau. After a series of operations, it was recommended for further use [30].

Aesthetic results after breast reconstruction may be unstable in nature. Ptosis of the prosthesis may occur due to the individual characteristics of the connective tissue and its tendency to hyperextension [31]. V.G. Mishalov indicated that a significant percentage of recurrence of gravitational ptosis after mammoplasty reflects the quality of fastening tissue, and remains an unsolved problem. The main idea proposed by Mr. V. Mishalov and co-authors in their method was to stimulate the formation of the connective tissue forming a «lock» to fix soft tissue to a stable structure using [32].

In the P.A. Hertsen's Moscow Cancer Research Institute, Department of General Oncology, from 2008 to 2011, 35 onestep reconstructions of the breast for cancer were performed using pectoralis major muscle, silicone implant and mesh implant. Early postoperative complications occurred in $5(14,3 \%)$ patients: marginal skin necrosis - $1(2,85 \%)$, diffuse bleeding $-1(2,8 \%)$, suppuration of postoperative wound -1 $(2,85 \%)$, wound dehiscence $-2(5,7 \%)$ [33].

Currently reticulated polymeric titanium and polyester implants are widely used for reconstructive surgery, including breast reconstruction. Titanium mesh implants are made of a unique patented composite material with covalently bound coating titanium. Macroporous prosthetic mesh consists of polypropylene monofilaments with a covalently bound coating of titanium (30 nanometers, while retaining the flexibility of the polymer), tensile strength and elongation correspond to the dynamics of body tissues and it is used to support and enhance connective tissue structures and ligaments.
The main methodical purpose of using mesh implants in breast reconstruction is to increase subpectoral space for the installation of silicone prosthesis, reduction of the pressure on the skin, to ensure good coverage of the prosthesis. Due to the formation of a new tissue layer, whose cells grow out through the pores of the mesh implant are surrounded by patients' own tissue. The frequency of postoperative complications when performing one-step breast reconstruction after subcutaneous mastectomy with mesh implant and silicone implant is not higher than the one observed during other types of reconstruction [33-35], which allows to implement this method.

Plastic and reconstructive surgery has been continuously developing, improving the existing methods due to the advanced scientific research. A promising area in the reconstructive breast surgery is the use of biological implant acellular dermal matrix (ADM). ADM was originally designed to correct the shape of the breast after augmentation to eliminate all roughness and contour abnormalities. Its use in implantation became popular after Brueing et al. published several cases of its application to cover the lower lateral pole of the breast [36]. Several cases of the application in two-step reconstruction with tissue expander were published later.

The use of ADM became common in 2005. Using biomaterial made it possible to create a pocket for prosthesis/tissue expander without using anterior serratus muscle or rectus abdominis [37].

The advantages of ADM are as follows: it decreases the postoperative pain syndrome intensity, prevents damage of the donor area and improves aesthetic results [36-41]. However, there are indications in medical articles about an increase in the number of postoperative infectious complications, seromas, and explantations [37, 39, 43-45].

Nowadays, the majority of dermal matrices used for breast reconstruction include the human matrix, porcine matrix or matrix from cattle. Human matrix is made by Alloderm (LifeCell, Branchburg, NJ), Flex HD (Ethicon, Sommerville, NJ), Neoform (Mentor, Santa Barbara, CA), and DermaMatrix (Synthes, West Chester, PA); the porcine matrix - by Strattice (LifeCell, Branchburg, NJ) and Permacol (Covidien, Boulder, CO). The matrix of cattle is only presented on the market in the form of Surgimend (TEI Biosciences, Boston, MA). ADM can be used in immediate and delayed breast reconstruction. Immediate reconstruction has certain advantages: preservation of skin case and favorable conditions for the formation of a pocket for a prosthesis [46].

The method of using ADM was first described for one-step reconstruction with a permanent implant to reduce or eliminate installation of a tissue expander. In the original report of Breuing as well as in five subsequent randomized studies the effectiveness and success of immediate reconstruction when using ADM were proven [38, 41, 42, 47-49]. In these retrospective studies, the overall incidence of complications was between $6,9 \%$ and $25 \%$. Breuing reported $6,9 \%(2 / 30)$ of complications after primary reconstructions, Zienowicz's et al. reported $25 \%(6 / 24)$ of complications due to the necrosis of skin grafts, the treatment of which was carried out using local methods. The greatest review of one-step reconstruction with implants and ADM was presented by Colwell et al.: the complication rate was $14,8 \%$ (49/331), including 9,1 percent 
(30/331) cases of the necrosis of skin grafts. Skin graft necrosis that required the removal of the prosthesis occurred in $1,5 \%$. These results demonstrated the successful application of ADM in one-stage breast reconstruction.

A proper selection of patients is required to achieve the best possible results. Excellent condition of skin grafts is required. Moreover, patients should be informed that for the best possible result the breast size has to be similar to natural or smaller 48].

One of the advantages of ADM is the reduction of pain syndrome due to the reduction of pectoralis major muscle tension $[36,50]$.

The use of ADM was first described for capsular contracture treatment. Currently, there are no data proving the prevention the development of capsular contracture when using ADM [36, $41,51-53]$. Some authors point out that ADM provides the best aesthetic results, but there are only 2 studies that support this assertion. Spear et al. got identical results according to the reconstruction with implants and ADM (a mean of 3,68 out of a possible 5) and the contralateral unreconstructed breast (a mean of 3,98 out of a possible 5$)(p=0,3)[54,55]$. Vardanian et al. also showed that the overall aesthetic result, evaluated by independent observers on a scale of 1-4 was, statistically, significantly larger in the group with ADM's - 3,26, compared with the group without $A D M-2,87$. According to the author, the submammary fold was in the best position in the group with ADM - 3,35, compared with the group without ADM - 2,94 [50].

Complications in the application of ADM are similar to those of breast reconstruction with implants, and should be divided into early ones - hematoma, seroma, infection, necrosis of skin grafts, rejection of the prosthesis, and late complications such as asymmetry, wrinkling of the implant, wrong position, capsular contracture, and late infectious complications. Hematoma occurs in less than $5 \%$ of cases, and treatment of that is standardized for all reconstructions. ADM implies the increased risk of developing seroma, and there are two studies which have shown a statistically increased frequency of that $[36,40]$. Chun points out the development of seroma - $14,1 \%$ in the group with ADM compared with $2,7 \%$ in the group without ADM [36]. Similarly, Parks reported a $29,9 \%$ seromas in ADM group and $15,7 \%$ in the group without ADM [40]. However, there are many studies that show no statistically significant difference in the development of seromas caused by ADM [37, $41,45,52,54,56]$. Thus, according to Liu et al., seroma frequency was $7.1 \%$ in the ADM group versus $3,9 \%$ in the group without ADM, while according to Lanier et al., it was $13,4 \%$ versus $6,7 \%$, respectively, the data did not reach the statistical significance. Taking into account these conclusions, it should be pointed out that in order to minimize the risk of seroma development the installation of vacuum drainage without its premature removal should be used.

Infectious complications when using ADM are observed in a high percentage of patients - 35,4 percent, which may be explained by the presence of the second foreign material, in addition to the endoprosthesis. There are many reports that demonstrate increase in the number of infectious complications in patients with ADM [36, 37, 44, 45, 57-59]. Timely antibiotic therapy is important.

Contraindications for ADM use are similar to those with endoprosthesis mammoplasty. Selection factors include an as- sessment of the need for unilateral or bilateral reconstruction, body type, body mass index, width of the chest, comorbidities, and psychological portrait of the patient. Ideal candidates for reconstruction with implants and ADM are skinny patients who are undergoing bilateral reconstruction after adequate mastectomy skin flaps and skinny patients with breast without pthosis undergoing unilateral reconstruction. With increasing size and ptosis of the breast, it is more difficult to achieve symmetry, therefore contralateral mastopexy or reduction mammoplasty become necessary

Nowadays, there are no absolute contraindications for ADM using, however, obesity, smoking and breast size more than 600 grams mean increased risk of postoperative complications. The combination of ablasticity and surgery reconstructive techniques is necessary to achieve the best results. All cuts must be pre-marked, submammary fold must be marked and, if possible, preserved during the mastectomy, skin flaps should be thick enough to preserve adequate circulation and to prevent possible loss of the skin graft [37, 44, 45].

In our opinion, the selection criterion for strengthening the lower slope of the breast in subcutaneous or skin-saving mastectomy with silicone implant in the cancer treatment with onestep reconstruction is the value of pinch-test. When the value of the pinch-test is more than $0,5 \mathrm{~cm}$, a synthetic implant and ADM can be used. When the value of the pinch-test is less than $0,5 \mathrm{~cm}$, the preference should be given to ADM.

\section{MATERIALS AND METHODS}

During 2014-2015, in the Department of Oncology and reconstructive surgery of breast and skin of the P.A. Hertsen Moscow Cancer Research Institute, 44 operations were performed with the use of synthetic implants and acellular dermal matrix for the treatment of 38 patients with breast cancer and 1 patient with multiple geliomas because of silicone implant rupture. The age of patients ranged from 32 to 67 years (mean 42,2). 0 TisNOM0 stage breast cancer was diagnosed in 6 patients, T1N0M0 I - 14, IIA T1N1M0-4, T2N0M0-10, T2N1M0 IIB - 2, IIIA T1N2M0-1, IIIC T2N3M0-1. Neoadjuvant drug treatment was given to 6 patients. According to the histological examination of invasive cancer, 30 patients were diagnosed without evidence of specificity, invasive lobular -2 , in situ - 6. A tumor node up to $1 \mathrm{~cm}$ was detected in 7 patients, 1 to $2 \mathrm{~cm}-16$, from 2 to $5 \mathrm{~cm}-15$. Metastases to 4 of lymph nodes were detected in 6 patients from 4 to 10 to 1 , subclavian lymph nodes metastases - 1. Cancer vascular embolism was diagnosed in 3 cases. Degree of malignancy of invasive cancer was detected in 30 cases: $G_{1}-4, G_{2}-21, G_{3}-5$. According to the immune-histochemical study, the luminal type $A$ was found in14 cases, luminal type b, Her2/neu-negative subtype - in 9, luminal type b, Her2/neu-positive subtype - in 2, Her2/neu-positive subtype - in 4, triple negative subtype - in 7 cases. Radical subcutaneous mastectomy was performed in 21 cases, subcutaneous mastectomy about gelioma - in 1, skin-saving radical mastectomy - in 17 cases. Silicone implant volume ranged from 215 to $585 \mathrm{~cm} 3$ and depended on the individual anatomy of the patient (mean $=375 \mathrm{~cm} 3$ ). Mutations of the BRCA1 gene were found in 5 patients, and therefore prophylactic contralateral subcutaneous mastectomy was 
made with the strengthening of the lower slope of the reconstructed mesh implant. To achieve symmetry, augmentation of the contralateral breast was performed in 8 cases.

To strengthen the lower slope of the breast, operated on for cancer, titanium and mesh implants were used in 12 patients, implants polyester mesh Parietex - in 16, acellular dermal matrix Permacol - in 11 cases.

\section{The technique of using a biological implant in breast reconstruction}

After mastectomy, and careful hemostasis, pockets of skin were formed (Fig. 1, 2). Inferolateral part of the pectoralis major muscle was separated from the anterior chest wall. By using electro-dissection the subpectoral pocket was formed, up to the marked levels on the perimeter of the modeled breast. After successfully creating the subpectoral pocket we performed preparation of ADM sheet, according to the manufacturer's recommendations. On the next stageADM was hemmed to the chest wall with reconstruction of the lateral and lower submammary fold (Fig. 3). Most surgeons prefer using absorbable seam materials, in particular, 2-0 polydioxanone (PDS) or Vicryl 2-0. After reliable attachment of the ADM to inframammary fold, the width of the pocket was measured in order to select a pros- thesis. After careful hemostasis in the pocket and a prosthesis placement, the edge of ADM was hemmed to the bottom and the side edges of the pectoralis major muscle. For a reliable cover, silicone prosthesis was isolated on the serratus anterior and ADM was fixed to the last one in the lateral section. In all cases, a closed space was formed with a tight fit of the prosthesis, but without pressure on the skin flaps (Fig. 4, 5). The wound was seamed in layers, with two vacuum drains left (Fig. 6).

\section{The Technique of Radical Subcutaneous Mastectomy with Simultaneous Reconstruction with the \\ Mesh Implant and Silicone Implant}

According to the preoperative marking by periareolar line in the case of a subcutaneous mastectomy or by two radial cuts at skin-saving mastectomy, we dissected the skin and subcutaneous tissues were cut. Skin flaps were separated widely. Mammary gland with a tumor was mobilized and removed subcutaneously. Axillary-subscapular tissue was removed. In case of a lymph node, axillary-subclavian-subscapular lymphadenectomy was performed. The pectoralis major muscle was separated from the pectoralis minor to 3 and 9 o'clock positions. Mesh implant was fixed to the great pectoral muscle edge by non-absorbable suture atraumatic thread. The silicone implant was

\section{The Reconstruction Step when Using Silicone Implant and ADM}

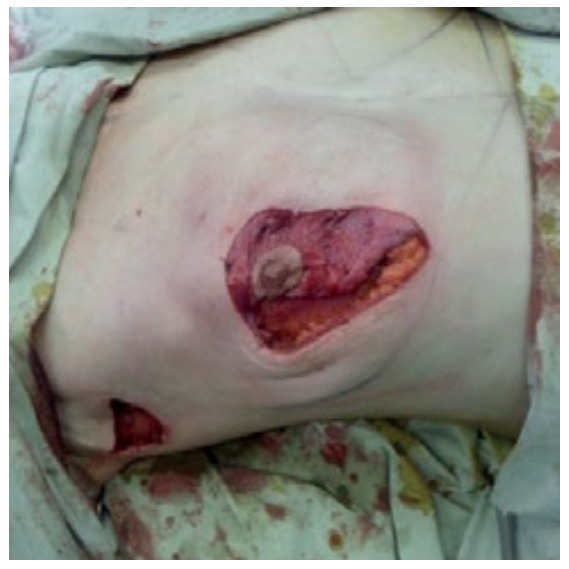

Fig. 1. The wound view after subcutaneous mastectomy and axillary subscapular lymph node dissection.

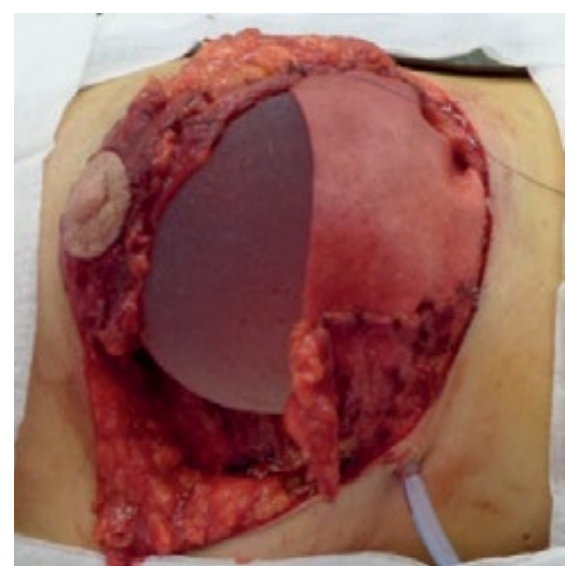

Fig. 4. The step of pocket forming using the major pectoral muscle, and acellular dermal matrix, serratus anterior, fascia of musclus rectus abdominis.

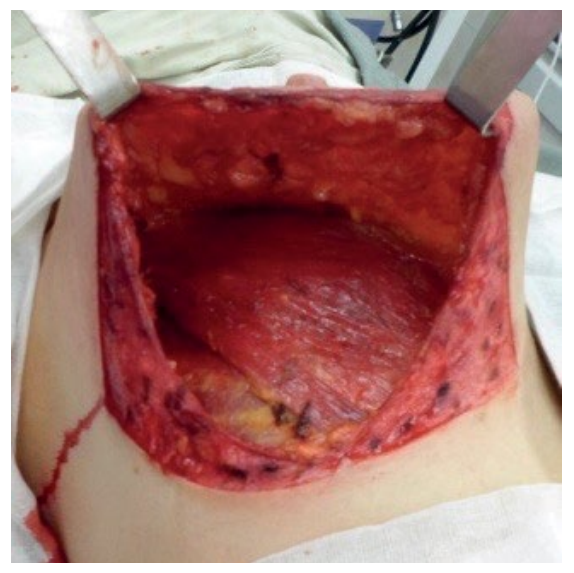

Fig. 2. The wound view of the cavity after completing a subcutaneous mastectomy.

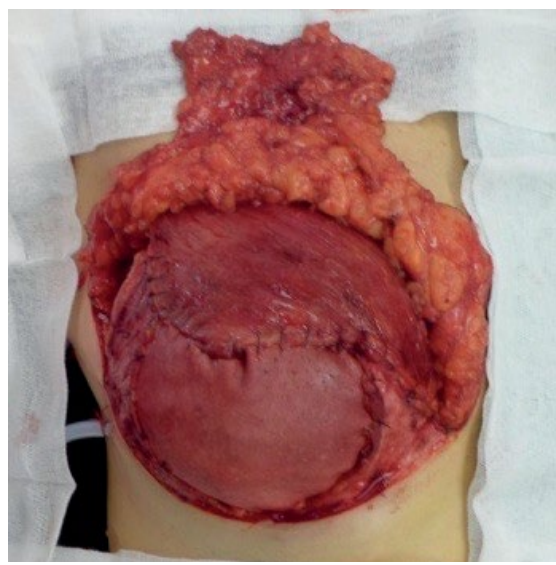

Fig. 5. The final view of the pocket formed with endoprosthesis.

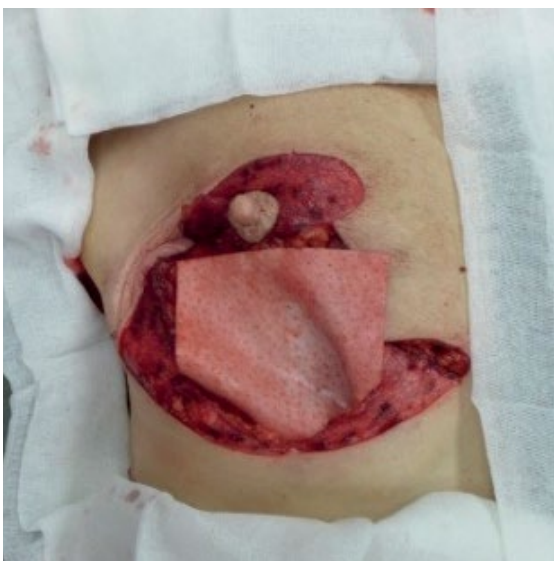

Fig. 3. ADM is fixed to the inframammary fold.

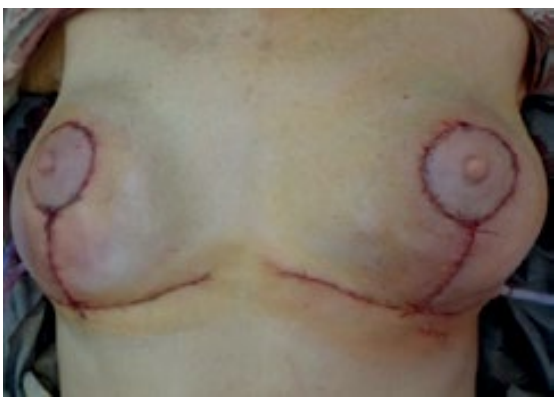

Fig. 6 . The view of postoperative wounds 
placed under pectoralis major muscle and covered by mesh implant. A duplicator of the mesh implant was formed. At the lateral side, mesh was fixed to anterior serratus muscle to prevent its displacement. Vacuum drainage was placed in the space of the prosthesis and axillar region. After an aseptic dressing, patients were asked to wear elastic compression underwear.

\section{RESULTS}

In the group of patients with ADM, the development of skin grafts necrosis at lower quadrants was found in 1 patient at the early postoperative period. Because of that, three necrotomies with the imposition of secondary sutures were carried out with a temporary positive result. Progressive marginal necrosis required secondary sutures, autodermoplasty and subsequent replacement of the cutaneous-subcutaneous flap from the anterior chest wall, which led to good result. It should be pointed out that the development of seromas and infectious complications in this patient were not observed, and 2 courses of antibiotic prophylaxis were conducted. The only change in the aesthetic result is only due to the appearance of additional seams after autodermoplasty in the area of the lower quadrants; significant changes in the shape of a breast were not marked. The presence of ADM, which covered the endoprosthesis, allowed to avoid the re-implantation of the last one.

The development of a long-standing small seroma in the central parts of the postoperative scar occurred in 1 patient during early postoperative period. A puncture was performed and topical treatment provided with seroma regression noted a month after surgery. In 1 case, during adjuvant chemotherapy, within 4 months after the operation, the development of skin reactions, such as redness in the area reconstructed with the endoprosthesis and ADM breast, required hormonal and anti-inflammatory topical treatment, a common antihistamine therapy with a positive result. In 2 (18\%) cases, ADM and implant were removed in connection with suppuration of postoperative wound.

In the ADM group, excellent cosmetic results were observed in $5(46 \%)$ cases, good - in $4(36 \%)$, unsatisfactory in $2(18 \%)$ cases. Views of a patients before and after surgery with ADM is given in Fig. 7-14.

In the group with application of titanium and mesh implants, the endoprosthesis was removed in 2 cases because of the development of bedsores in the lower-medial division of the reconstructed breast. In the group where polyester mesh implants were used, the implant was removed in 1 case due to diastasis of surgical wounds, the inefficiency of multiple sec-
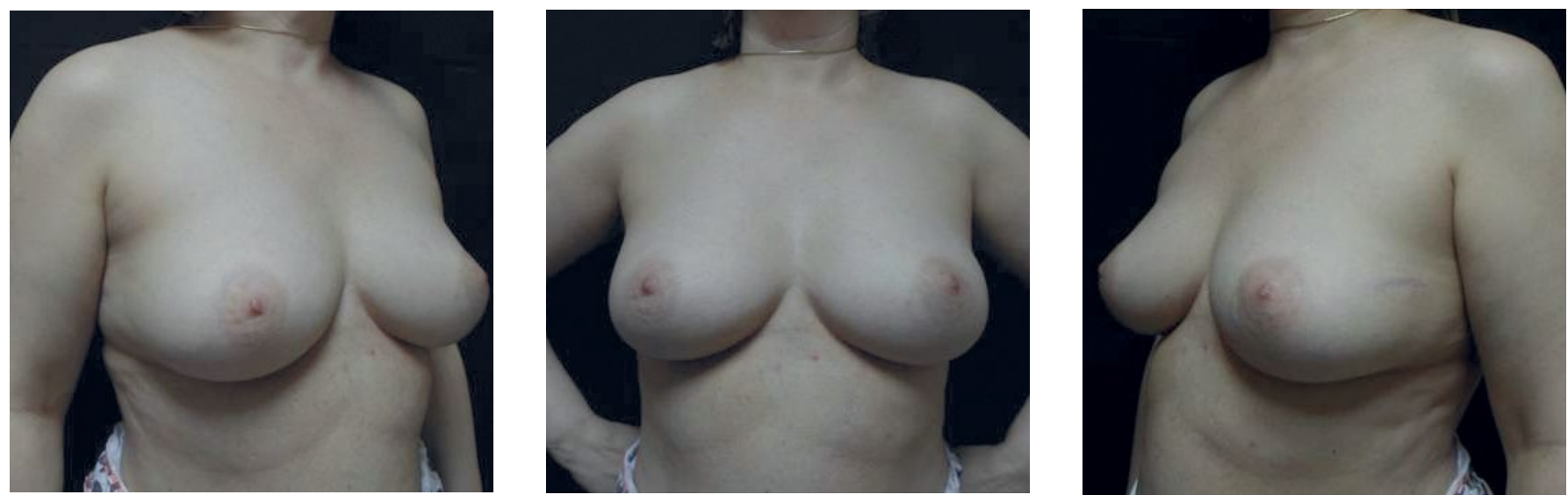

Fig. 7, 8, 9. The view of a patient in the three projections prior to surgery. Clinical diagnosis: left side breast cancer ypT2NOMOG2LOVOPR. stage IIA, Her2/neu-positive subtype, the state after a 8 courses of neoadjuvant drug therapy.
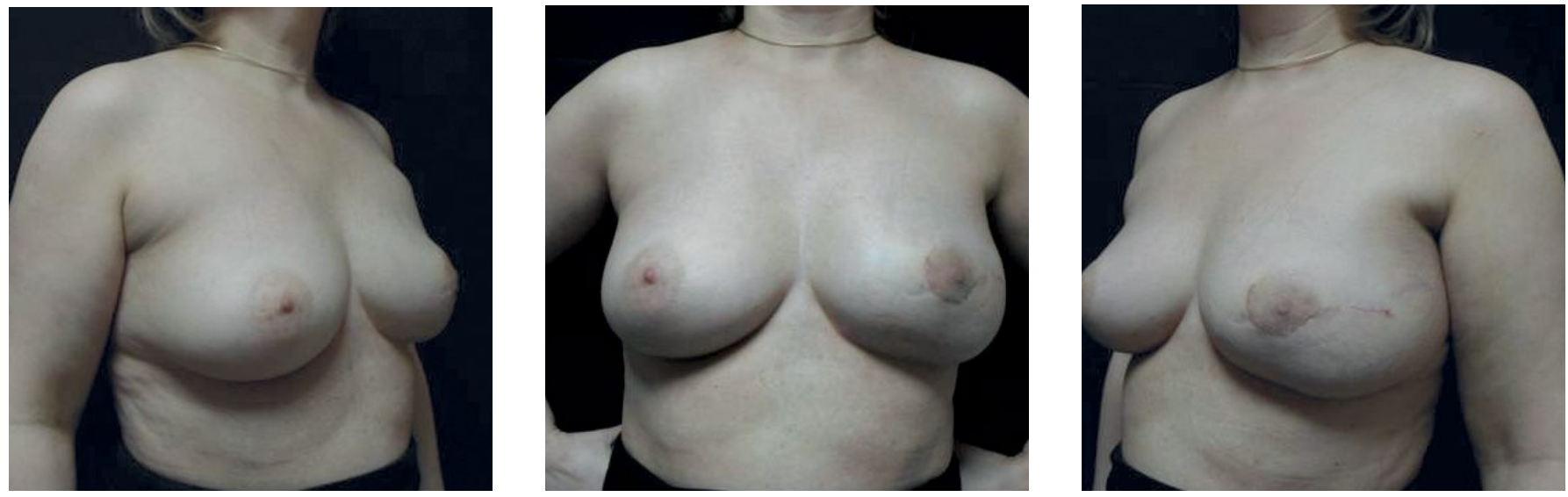

Fig. 10,11, 12. View of the patient in the three projections a month after radical subcutaneous mastectomy on the left breast with one-stage reconstruction with silicone implant and ADM. 

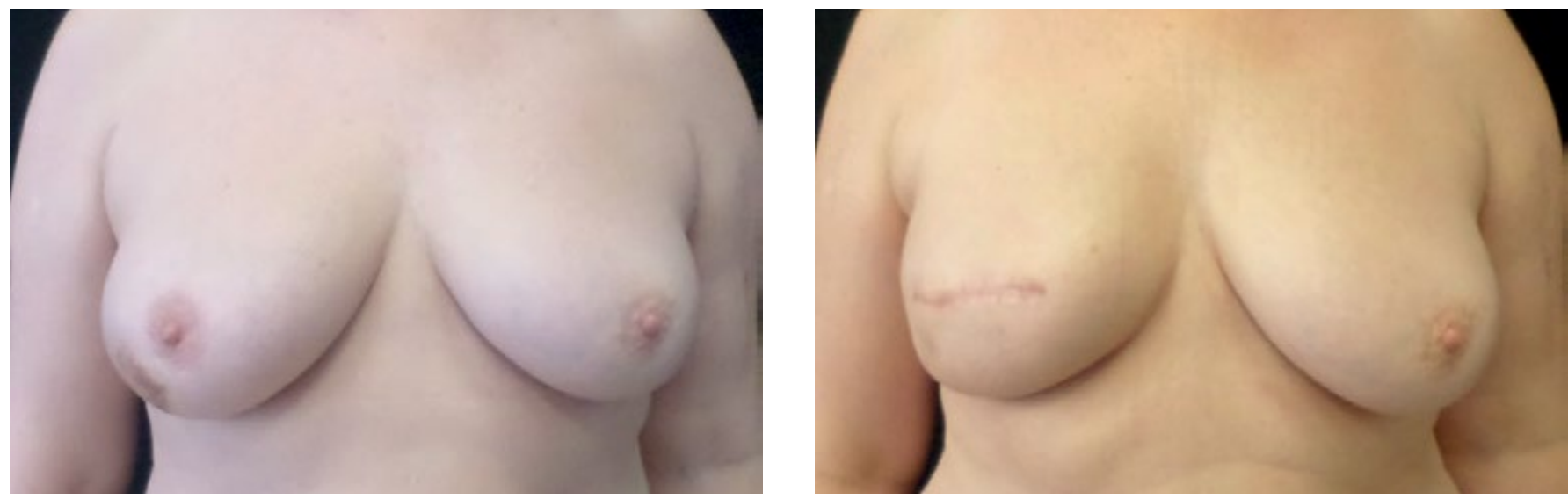

Fig. 13, 14. View the patient before and after 20 days after skin-sparing radical mastectomy with immediate reconstruction of the silicone implant and mesh implant.

\section{ondary seams.}

In the group where mesh implants were used, excellent cosmetic results were achieved in $16(57 \%)$ patients, good - in 9 $(32 \%)$, unsatisfactory - in $3(11 \%)$ cases. View of the patient before and after surgery with mesh implant is given in Fig. 13, 14.

From the total number of patients $(n=39)$, excellent cosmetic results were noticed in 21 cases (54\%), good - in $13(33 \%)$ and unsatisfactory - in $5(13 \%)$ cases (due to the removal of the implants).

\section{CONCLUSIONS}

Biological and synthetic materials are significantly important options for breast reconstruction. Their advantages are as follows: they reduce surgical trauma during one-step reconstruction by making the use of autologous muscle grafts unnecessary, they reduce operation time and pain, they make it possible to expand the prosthesis pocket.

The value of pinch-test is the selection criterion to strengthen the lower slope of breast during skin-sparing subcutaneous mastectomy in cancer treatment with one-step reconstruction with silicone implant. When the value of the pinch-test is over $0.5 \mathrm{~cm}$ a synthetic implant can be used as well as ADM. When the value of the pinch-test is lower than $0.5 \mathrm{~cm}$ the preference should be given to ADM.

According to certain articles, there is increased risk of infection in the reconstruction area when using ADM, surgeons should be aware of and take timely preventive measures.

\section{References}

1. Malignant neoplasms in Russia in 2013 (Morbidity and mortality). Edited by Kaprin AD, Starinsky VV, Petrova GV. Moscow, 2015 . (In Russian). Availavle at: http://www. oncology.ru/service/statistics/malignant_tumors/2013.pdf

2. Aseev VA. Psychological issues associated with breast cancer. Clinical Medicine. 1993; 3: 30-34. (In Russian).

3. Awan BA, Samargandi OA, Alghamdi HA, Sayegh AA, Hakeem YJ, Merdad L, et al. The desire to utilize postmastectomy breast reconstruction in Saudi Arabian women. Predictors and barriers. Saudi Med J. 2015 Feb; 36 (3): 304-9. DOI: 10.15537/smj.2015.3.10688

4. Morrow MLi Y, Alderman AK, Jagsi R, Hamilton AS, Graff JJ, Hawley ST, et al. Access to breast reconstruction after mastectomy and patient perspectives on reconstruction decision making. JAMA Surg. 2014 Oct; 149 (10): 1015-21. DOI: 10.1001/jamasurg. 2014.548

5. Reshetov IV, Chissov VI. Plasticheskaya i rekonstruktivnaya mikrokhirurgiya v onkologii [Plastic and reconstructive microsurgery in Oncology]. Moscow, 2001, $200 \mathrm{p}$. (In Russian).

6. Chalnot P, Michon J. Le dedoublement du sein restant. Ann Chir Plast. 1958; 3: 35. 7. Semiglazov VF. Minimal breast cancer. Leningrad: Medicine, 1992, 276 p. (In Russian).

8. Sharova ON, Vasilyev SA, Buoys VA, Vazhenin AV. Breast reconstruction as the most constructive mechanisms of psychological protection in women after radical treatment of breast cancer. Annals of plastic, reconstructive and aesthetic surgery. 2001; 1: 43-49. (In Russian).

9. Malygin EN, Malygin ES, Andrianov OV. one-stage reconstructive plastic opera-

tions in patients with breast cancer. Abstracts of the II Congress of CIS oncologists "Oncology 2000". Kiev, 23-26 May 2000. (In Russian).

10. Kaviani A, Safavi A, Mirsharifi R. Immediate and delayed contralateral symmetrization in oncoplastic breast reduction: patients' choices and technique formulation. Plast Reconstr Surg Glob Open. 2015 Feb 6; 3 (1): 286. DOI: 10.1097/GOX.0000000000000246

11. Burlakov $S$. Reconstructive surgery in the treatment of patients with breast cancer. Bulletin of Moscow Cancer Society. 2002; 9: 1-8. (In Russian).

12. Omranipour R, Bobin JY, Esouyeh M. Skin Sparing Mastectomy and Immediate Breast Reconstruction (SSMIR) for early breast cancer: eight years single institution experience. World J Surg Oncol. 2008 Apr 27; 6: 43. DOI: 10.1186/1477-7819-6-43 13. Pacifico MD, See MS, Cavale N, Collyer J, Francis I, Jones ME, et al. Preoperative planning for DIEP breast reconstruction: early experience of the use of computerised tomography angiography with VoNavix 3D software for perforator navigation. J Plast Reconstr Aesthet Surg. 2009 Nov; 62 (11): 1464-1469. DOI: 10.1016/j. bjps.2008.04.056

14. Rietjens M, De Lorenzi F, Venturino M, Petit JY. The suspension technique to avoid the use of tissue expanders in breast reconstruction. Ann Plast Surg. 2005 May; 54 (5): 467-70.

15. Spear SL, Bulan EJ. The medial periareolar approach to submuscular augmentation mammaplasty under local anesthesia: a 10-Year follow-up. Plast Reconstr Surg. 2001 Sep 1; 108 (3): 771-775

16. Spear SL, Newman MK, Bedford MS, Schwartz KA, Cohen M, Schwartz JS. A retrospective analysis of outcomes using three common methods for immedi- 
ate breast reconstruction. Plast Reconstr Surg. 2008 Aug; 122 (2): 340-347. DOI: 10.1097/PRS.0b013e31817d6009

17. Rezai M, Darsow M, Kummel S, Kramer S. Autologous and alloplastic breast reconstruction-overview of techniques, indications and results. Gynakol Geburtshilfliche Rundsch. 2008; 48 (2): 68-75. DOI: 10.1159/000118934

18. Borovikov AM. Vosstanovlenie grudi posle mastektomii [Breast reconstruction after mastectomy]. Moscow, 2000. (In Russian).

19. Ravipati NB, Pockaj BA, Harold KL. Laparoscopic mesh repair of transverse rectus abdominus muscle and deep inferior epigastric flap harvest site hernias. Surg Laparosc Endosc Percutan Tech. 2007 Aug; 17 (4): 345-348. DOI: 10.1097/SLE.0b013e3180640d91

20. Shons AR, Mosielo G. Postmastectomy Brest Reconstruction: Current Techniques. Cancer Control. 2001; 8 (5): 419-426.

21. Peter $G$, Cordeiro MD. Breast Reconstruction after Surgery for Breast Cancer. N Engl J Med. 2008; 359: 1590-1601. DOI: 10.1056/NEJMct0802899

22. Letterman $G$, Schurter $M$. Reconstruction of the breast following subcutaneous simple mastectomy. J Am Med Womens Assoc. 1968 Oct; 23 (10): 911-9115.

23. Cumberland VH. A preliminars report on the use of prefabricated nylon weave in the repair of ventral hernia. Med J Aust. 1952; 1: 143.

24. Scales JT. Discussion on metals and synthetic materials in relation to soft tissues: tissue reaction to synthetic materials. Proc R Soc Med. 1953; 46: 647.

25. Razumovsky AYu, Smirnov SV. The use of implants for plasty of the diaphragm in neonates. Surgery. 2012; 11: 90-95. (In Russian).

26. Spiegel AJ, Butler CE. Recurrence following treatment of ductal carcinoma in situ with skin-sparing mastectomy and immediate breast reconstruction. Plast Reconstr Surg. 2003; 111: 706-711. DOI: 10.1097/01.PRS.0000041440.12442.05

27. Fedorov IV. Prostheses in hernia surgery: a century of evolution. New surgical archive. 2002; 1 (4). (In Russian).

28. Loustau HD, Mayer HF, Sarrabayrouse M. Immediate prosthetic breast reconstruction: the ensured subpectoral pocket (ESP). J Plast Reconstr Aesthet Surg. 2007; 60 (11): 1233-1238. DOI: 10.1016/j.bjps.2006.11.007

29. Loustau HD, Mayer HF, Sarrabayrouse M. Pocket work for optimising outcomes in prosthetic breast reconstruction. J Plast Reconstr Aesthet Surg. 2009 May; 62 (5): 626-632. DOI: 10.1016/j.bjps.2007.08.037

30. Wettstein R, Elias B, Bächle A, Vlastos G, Harder Y. Dualmesh-muscle pocket with/without abdominal lift for immediate implant-based breast reconstruction after skin-sparing mastectomy. J Plast Reconstr Aesthet Surg. 2008. DOI: 10.1016/j. bjps.2008.11.043

31. Surkov N, Sarin SA, Vissarionov VA. Peculiarities of fibroarchitectonics of the connective tissue in the implantation of the mesh implant from prolina. Annals of plastic and reconstructive surgery. 2004; 2: 54-59. (In Russian).

32. Mishalov VG, Khrapach VV, Balaban OV. Unukovych DV, Nazarenko S, Sevchenko AS, et al. Method of improving fixation of soft tissues. Ukrainian Journal of Surgery. 2009; 5: 131-132. (In Ukrainian).

33. Troshenkov EA. Subcutaneous mastectomy with simultaneous reconstruction with silicone implants, and implant the mesh in patients with breast cancer. Diss. on competition. art PhD. Mosow, 2011, 125 p. (In Russian).

34. Meyer Ganz O, Tobalem M, Perneger T, Lam T, Modarressi A, Elias B, Pittet $B$. Risks and benefits of using an absorbable mesh in one-stage immediate breast reconstruction: a comparative study. Plast Reconstr Surg. 2015 Mar; 135 (3): 498e-507e. DOI: 10.1097/PRS.0000000000001027

35. Casella D, Bernini M, Bencini L, Roselli J, Lacaria MT, Martellucci J, et al. TiLoop® Bra mesh used for immediate breast reconstruction: comparison of retropectoral and subcutaneous implant placement in a prospective single-institution series. Eur J Plast Surg. 2014; 37 (11): 599-604. DOI: 10.1007/s00238-014-1001-1

36. Chun YS, Verma K, Rosen H, Lipsitz S, Morris D, Kenney P, et al. Implant-based breast reconstruction using acellular dermal matrix and the risk of postoperative complications. Plast Reconstr Surg. 2010 Feb; 125 (2): 429-436. DOI: 10.1097/PRS. ob013e3181c82d90
37. Lanier ST, Wang ED, Chen JJ, Arora BP, Katz SM, Gelfand MA, et al. The effect of acellular dermal matrix use on complication rates in tissue expander/implant breast reconstruction. Ann Plast Surg. 2010 May; 64 (5): 674-678. DOI: 10.1097/SAP.0b013e3181dba892

38. Glasberg SB, Light D. AlloDerm and Strattice in breast reconstruction: a comparison and techniques for optimizing outcomes. Plast Reconstr Surg. 2012; 129 (6): 1223-1233. DOI: 10.1097/PRS.0b013e31824ec429

39. Hoppe IC, Yueh JH, Wei CH, Ahuja NK, Patel PP, Datiashvili RO. Complications Following Expander/Implant Breast Reconstruction Utilizing Acellular Dermal Matrix: A Systematic Review and Meta-Analysis. Eplasty. 2011;11: e40

40. Salzberg CA. Nonexpansive immediate breast reconstruction using human acellular tissue matrix graft (AlloDerm). Ann Plast Surg. Jul 2006; 57 (1): 1-5. DOI: 10.1097/01.sap.0000214873.13102.9f

41. Seth AK, Hirsch EM, Fine NA, Kim JY. Breast Reconstruction — Current Perspectives and State of the Art Techniques. Utility of acellular dermis-assisted breast reconstruction in the setting of radiation: a comparative analysis. Plast Reconstr Surg. 2012; 130 (4): 750-758. DOI: 10.1097/PRS.0b013e318262f009

42. Zienowicz RJ, Karacaoglu E. Implant-based breast reconstruction with allograft. Plast Reconstr Surg. 2007; 120 (2): 373-381. DOI: $10.1097 / 01$. prs.0000267340.31742.1

43. Colwell AS, Damjanovic B, Zahedi B, Medford-Davis L, Hertl C, Austen WG, Jr. Retrospective review of 331 consecutive immediate single-stage implant reconstructions with acellular dermal matrix: indications, complications, trends, and costs. Plast Reconstr Surg. 2011; 128 (6): 1170-1178. DOI: 10.1097/PRS.0b013e318230c2f6

44. Nahabedian MY. AlloDerm performance in the setting of prosthetic breast surgery, infection, and irradiation. Plast Reconstr Surg. 2009; 124 (6): 1743-1753. DOI: 10.1097/PRS.0b013e3181bf8087

45. Weichman KE, Wilson SC, Weinstein AL, Hazen A, Levine JP, Choi M, et al. The use of acellular dermal matrix in immediate two-stage tissue expander breast reconstruction. Plast Reconstr Surg. 2012; 129 (5): 1049-1058. doi: 10.1097/PRS.0b013e31824a2acb

46. Weichman K, Disa J. Prosthetic Breast Reconstruction with Acellular Dermal Matrix. Breast Reconstruction - Current Perspectives and State of the Art Techniques. Chapter 4, pp. 67-80.

47. Breuing KH, Colwell AS. Inferolateral AlloDerm hammock for implant coverage in breast reconstruction. Ann Plast Surg. 2007; 59 (3): 250-255. DOI: 10.1097/SAP.0b013e31802f8426

48. Breuing KH, Warren SM. Immediate bilateral breast reconstruction with implants and inferolateral AlloDerm slings. Ann Plast Surg. 2005; 55 (3): 232-239.

49. Parks JR, Hammond SE, Walsh WW, Adams RL, Chandler RG, Luce EA. Human acellular dermis versus no acellular dermis in tissue expansion breast reconstruction. Plast Reconstr Surg. 2012 Oct;130 (4):739-46

50. Vardanian AJ, Clayton JL, Roostaeian J, Shirvanian V, Da Lio A, Lipa JE, et al. Comparison of implant-based immediate breast reconstruction with and without acellular dermal matrix. Plast Reconstr Surg. 2011; 128 (5): 403-410. DOI: 10.1097/PRS.0b013e31822b6637

51. Baxter RA. Intracapsular allogenic dermal grafts for breast implant-related problems. Plast Reconstr Surg. 2003; 112 (6): 1692-1696. DOI: 10.1097/01. PRS.0000086365.25453.C3

52. Becker S, Saint-Cyr M, Wong C, Dauwe P, Nagarkar P, Thornton JF, et al. AlloDerm versus DermaMatrix in immediate expander-based breast reconstruction: a preliminary comparison of complication profiles and material compliance. Plast Reconstr Surg. 2009; 123 (1): 1-6. DOI: 10.1097/PRS.0b013e3181904bff.

53. Bindingnavele V, Gaon M, Ota KS, Kulber DA, Lee DJ. Use of acellular cadaveric dermis and tissue expansion in postmastectomy breast reconstruction. J Plast Reconstr Aesthet Surg. 2007; 60 (11): 1214-1218. DOI: 10.1016/j.bjps.2007.03.015

54. Surgeons ASoP. American Society of Plastic Surgeons 2011 Statistics. 2011. Available at: http://www.plasticsurgery.org/News-and-Resources/2011-Statistics-html 55. Spear SL, Parikh PM, Reisin E, Menon NG. Acellular dermis-assisted breast re- 
construction. Aesthetic Plast Surg. 2008; 32 (3): 418-425. doi: 10.1007/s00266-0089128-8

56. Liu AS, Kao HK, Reish RG, Hergrueter CA, May JW, Jr, Guo L. Postoperative complications in prosthesis-based breast reconstruction using acellular dermal matrix. Plast Reconstr Surg. May; 127 (5): 1755-1762. DOI: 10.1097/PRS.0b013e31820cf233 57. Antony AK, McCarthy CM, Cordeiro PG, Mehrara BJ, Pusic AL, Teo EH, et al. Acellular human dermis implantation in 153 immediate two-stage tissue expander breast reconstructions: determining the incidence and significant predictors of complications.
Plast Reconstr Surg. 2010; 125 (6): 1606-1614. doi: 10.1097/PRS.0b013e3181d4fb2a

58. Gamboa-Bobadilla GM. Implant breast reconstruction using acellular dermal matrix. Ann Plast Surg. 2006; 56 (1): 22-25.

59. Topol BM, Dalton EF, Ponn T, Campbell CJ. Immediate single-stage breast reconstruction using implants and human acellular dermal tissue matrix with adjustment of the lower pole of the breast to reduce unwanted lift. Ann Plast Surg. 2008; 61 (5): 494-499. DOI: 10.1097/SAP.0b013e31816d82d9

Information about authors:

Maria V. Ermoshchenkova, PhD, researcher, surgeon, oncologist, plastic surgeon of the Department of Oncology and Reconstructive Plastic Breast and Skin Surgery of P. Hertsen Moscow Oncology Research Institute - Branch of the National Medical Research Radiological Centre of the Ministry of Health of the Russian Federation, associate professor of the Department of Oncology and Radiotherapy of the Institute of Professional Education, I. M. Sechenov First Moscow State Medical University. E-mail: maryerm@mail.ru

Aziz D. Zikiryakhodzhayev, PhD, MD, Professor of the Department of Oncology and Radiology, Peoples Friendship University of Russia, Head of the Department of Oncology and Reconstructive Surgery of the Mammary Gland and Skin, P. Hertsen Moscow Oncology Research Institute - Branch of the National Medical Research Radiological Centre of the Ministry of Health of the Russian Federation, associate professor of the Department of Oncology and Radiotherapy of the Institute of Professional Education, I. M. Sechenov First Moscow State Medical University ORCID: http://orcid.org/0000-0001-7141-2502

Valery I. Chissov, academician, MD, The Head of the Department of Oncology and Radiotherapy of The I. M. Sechenov First Moscow State Medical University of the Institute of Professional Education, The Adviser to General Director of P. Hertsen Moscow Oncology Research Institute - Branch of the National Medical Research Radiological Centre of the Ministry of Health of the Russian Federation

Anna S. Sukhotko, PhD, junior researcher of the Department of Oncology and Reconstructive Surgery of the Mammary Gland and Skin, P. Hertsen Moscow Oncology Research Institute — Branch of the National Medical Research Radiological Centre of the Ministry of Health of the Russian Federation. ORCID: http://orcid.org/0000-0002-2337-5919

Anton V. Usov, oncologist of Oncology Institute of European Medical Center in Moscow

A.Yu.Tukmakov, postgraduate student of the Department of Oncology and Radiotherapy of the Institute of Professional Education, I. M. Sechenov First Moscow State Medical University E. A. Baichorov, Associate Professor, The Stavropol State Medical University 